\title{
Cytogenetic and DNA barcoding reveals high divergence within the trahira, Hoplias malabaricus (Characiformes: Erythrinidae) from the lower Amazon River
}

\author{
Diego Ferreira Marques ${ }^{1,3}$, Fabíola Araújo dos Santos ${ }^{1,3}$, Simoni Santos da Silva ${ }^{2}$, \\ Iracilda Sampaio ${ }^{2}$ and Luís Reginaldo Ribeiro Rodrigues ${ }^{1}$
}

Molecular and cytogenetic data have provided evidence of cryptic speciation in the widespread South American trahira, Hoplias malabaricus. In the present study, karyotypes and DNA barcode sequences of specimens from seven populations inhabiting the lower Amazon River were analyzed in order to characterize the levels of genetic divergence within a single karyomorph. All the specimens presented karyotypes with $2 n=40$ chromosomes $(20 m+20 \mathrm{sm})$ that were consistent with the species' C karyomorph. The DNA barcodes revealed six haplogroups, with clear divergence between populations from Brazil and Argentina. The results support the species complex hypothesis and indicate that a single karyomorph of H. malabaricus may harbor more than one species.

Dados moleculares e citogenéticos tem evidenciado especiação críptica na traíra sul-americana, Hoplias malabaricus. No presente estudo, cariótipos e sequências de DNA barcode de espécimes de sete populações, habitando a região do baixo rio Amazonas, foram analisadas a fim de caracterizar o nível de divergência genética dentro de um único cariomorfo. Todos os espécimes possuem $2 n=40$ cromossomos $(20 m+20 \mathrm{sm})$ os quais são inseridos no grupo de traíras do cariomorfo C. DNA barcode revelou seis haplogrupos, com clara divergência entre populações do Brasil e da Argentina. Os resultados apoiam a hipótese de complexo de espécies e indicam que um único cariomorfo de Hoplias malabaricus pode conter mais de uma espécie.

Key words: Amazon basin, COI, Karyomorph, Species complex, Trahiras.

\section{Introduction}

The fishes of the family Erythrinidae are a small group of Neotropical characiforms distributed in three genera: Erythrinus Scopoli, 1777, Hoplerythrinus Gill, 1896, and Hoplias Gill, 1903 (Nelson, 2006). At least fifteen nominal erythrinid species are currently recognized (Oyakawa, 2003; Oyakawa \& Mattox, 2009).

Hoplias is the most diverse genus, with ten species arranged in two groups. The Hoplias lacerdae group contains nine species - H. aimara (Valenciennes, 1847), H. brasiliensis (Spix \& Agassiz, 1829), H. lacerdae Miranda Ribeiro, 1908, H. intermedius (Günther, 1864), H. microlepis (Günther, 1864), H. patana (Valenciennes, 1847), H. teres (Valenciennes, 1847),
H. curupira Oyakawa \& Mattox, 2009, and H. australis Oyakawa \& Mattox, 2009. The monotypic Hoplias malabaricus group is composed of $H$. malabaricus (Bloch, 1794), which is believed to encompass a species complex (Bertollo et al., 2000; Dergam et al., 2002; Santos et al., 2009).

The trahira Hoplias malabaricus is a common species found in lentic habitats in the most of the river basins of South America (Nelson, 2006). This species has been studied intensively using a cytogenetic approach, which revealed a karyotypic polymorphism among populations from distinct river basins (Bertollo et al., 2000; Rosa et al., 2009; Santos et al., 2009; Blanco et al., 2010). Seven karyomorphs (denominated A-G) have been identified based on diploid number and chromosome morphology, and are currently

${ }^{1}$ Universidade Federal do Oeste do Pará (UFOPA), Laboratório de Genética \& Biodiversidade, Campus Tapajós, Rua Vera Paz, SN. Salé, 68035-110 Santarém, PA, Brazil.marqudiego@gmail.com(DFM), fabiola_santos_22@hotmail.com(FAS), luisreginaldo.ufpa@hotmail.com (LRRR)

${ }^{2}$ Universidade Federal do Pará (UFPA), Laboratório de Genética e Biologia Molecular, Campus Universitário de Bragança, Alameda Leandro Ribeiro s/n. Bairro Aldeia, 68600-000 Bragança, PA, Brazil. simony@ufpa.br (SSS), ira@ufpa.br (IS)

${ }^{3}$ Master Science student, PPGRNA-UFOPA. 
recognized as distinct independent evolutionary units (Bertollo et al., 2000). A new karyomorph from the Araguaia River was recently reported by Vitorino et al. (2011).

The A, C, E, F, and G karyomorphs have been collected in the Amazon basin, although the A, C, and F karyomorphs occur outside this basin in eastern and southern Brazil, the $\mathrm{G}$ and $\mathrm{E}$ karyomorphs seem to be restricted to a small number of Amazonian localities (Bertollo et al., 2000).

The lack of records of hybrids from areas in which distinct karyomorphs are sympatric has been considered to be strong evidence for the existence of a species complex (Scavone et al., 1994; Lopes et al., 1998; Bertollo et al., 2000; Pazza \& Júlio, 2003; Rosa et al., 2009.). This conclusion was further reinforced by morphological (Rosa et al., 2009; Piorsky, 2010) and molecular data (Dergam et al., 1998; 2002; Santos et al., 2009; Piorsky, 2010; Pereira et al., 2013). Thus, the available chromosomal, morphological and DNA evidence provide strong support for the existence of a complex of cryptic species within the typical Hoplias malabaricus morphotype, which requires careful taxonomic revision.

The accurate delimitation of species is a classic problem of the biological sciences. Recently, DNA barcoding has become an increasingly popular approach to the delimitation of species (Hebert et al., 2003; Blaxter, 2004; Ward et al., 2005, 2009; Kerr et al., 2007, 2009; Steinke et al., 2009; Casiraghi et al., 2010). In this approach, a partial sequence of the cytochrome $c$ oxidase subunit I gene (COI) has been standardized as a DNA barcode for the analysis of animal groups, including cryptic species complexes (Hebert et al., 2004a, 2004b; Hubert et al., 2008; Lara et al., 2010; Allcock et al., 2011).

In order to contribute to a better understanding of the evolutionary history and diversification of the Hoplias malabaricus species complex, we analyzed DNA barcodes and karyotypes of specimens representing karyomorph $\mathrm{C}$ from the Amazon basin. To assess the geographical structure we compared DNA barcodes of specimens from Amazon Basin and São Francisco River basin (Brazil) and Pampa plain region (Argentina). Our principal objective was to test the hypothesis that a given karyomorph could represent a single species.

\section{Material and Methods}

\section{Sampling and karyotypes}

A total of 35 specimens of Hoplias malabaricus were collected from seven sites located along a $350 \mathrm{~km}$ stretch of the main channel of lower Amazon River in the Brazilian state of Pará (Table 1, Fig. 1). Specimen collection was authorized by the Instituto Chico Mendes, Brazil, through special license number 24384-1. All the specimens were identified as $H$. malabaricus based on their external morphology, using the diagnostic characters provided by Oyakawa \& Mattox (2009). Voucher specimens (UFOPA-I 301 - 335) were photographed, fixed in $10 \%$ formalin and stored in $70 \%$ ethanol, and deposited in the fish collection of the Zoology Museum at the Universidade Federal do Oeste do Pará (UFOPA), Brazil.

For comparative purposes with further studies, morphological measurements of selected specimens are given in Table 2. Such variables were examined taken point-to-point along the left side of the specimen and were taken with digital callipers with a precision of $0.01 \mathrm{~mm}$ following Rosa et al. (2009).

Karyotypes were prepared from kidney cells following the protocol of Bertollo et al. (1978). Cytogenetic parameters such as the diploid number (2n), karyotypic formula and C-banding (Sumner, 1972) were used for the identification of karyomorphs. For the purposes of the present study, each karyomorph that was defined using these criteria was assumed to represent a distinct species.

\section{DNA extraction, PCRs and sequencing}

Fragments of the heart tissue of each specimen were collected and fixed in ethanol 95\%. Genomic DNA extraction was carried out using the standard phenol-chlorophorm protocol (Sambrook et al., 1989).

A 652-bp segment of the 5' region of the mitochondrial COI gene (Accession numbers: JX112659-JX112693) was amplified by Polymerase Chain Reaction (PCR) using the COI3 M13-tailed primer cocktail (for details, see Ivanova et al., 2007). The PCRs were conducted in a final volume of $25 \mu \mathrm{L}$, constituted of: $4 \mu \mathrm{L}$ of dNTPs ( $1.25 \mathrm{mM}), 2.5 \mu \mathrm{L}$ of $10 \mathrm{X}$ buffer (200mM Tris-HCl, $\mathrm{pH} 8.4$ and $500 \mathrm{mM} \mathrm{KCl}), 1 \mu \mathrm{L}$ of $\mathrm{MgCl}_{2}(50$ $\mathrm{mM}), 1-1.5 \mu \mathrm{L}$ of genomic DNA solution, $0.2 \mu \mathrm{L}$ of each primer $(1 \mu \mathrm{M}), 0.2 \mu \mathrm{L}$ of Taq polymerase $(5 \mathrm{U} / \mu \mathrm{L})$ and purified water to complete the final volume.

The PCR cycle was as follows: initial denaturing at $94^{\circ} \mathrm{C}$ for 3 minutes, followed by 35 cycles of denaturing at $94^{\circ} \mathrm{C}$ for 30 seconds, annealing at $59^{\circ} \mathrm{C}$ for 1 minute, extension at $72^{\circ} \mathrm{C}$ for 2 minutes, and a final extension at $72^{\circ} \mathrm{C}$ for 7 minutes. The products were checked on a $1 \%$ Agarose gel stained with GelRed and the positive reactions were purified using Exosap IT Kit (GE Healthcare) according to the manufacturer's instructions. Barcode sequences were obtained using the ABI Prism Big Dye terminator sequencing kit V.3 (Perkin Elmer)

Table 1. Samples, collect sites and collection numbers of Hoplias malabaricus from Amazon basin.

\begin{tabular}{|c|c|c|c|}
\hline Localities & GPS coordinates & $\mathrm{n}$ & Field numbers \\
\hline Sapucuá lake & 147'11.6”S - 55'59'34.6”W & 5 & SAP-1, SAP-3, SAP-4, SAP-5, SAP-17 \\
\hline Óbidos & $1^{\circ} 54^{\prime} 58.2^{\prime \prime} \mathrm{S}-55^{\circ} 26^{\prime} 20.5^{\prime \prime} \mathrm{W}$ & 9 & OBI-1, OBI-2, OBI-11, OBI-12, OBI-14, OBI-15, OBI-17, OBI-18, OBI-19, \\
\hline Juá lake & $2^{\circ} 26^{\prime} 40.0 ” S-54^{\circ} 47^{\prime} 21.1^{\prime \prime} \mathrm{W}$ & 5 & JUA-3, JUA-9, JUA-13, JUA-14, JUA-15 \\
\hline Maicá lake & $2^{\circ} 27^{\prime} 30.3{ }^{\prime \prime S}-54^{\circ} 40^{\prime} 13.2^{\prime \prime W}$ & 7 & MAI-2, MAI-3, MAI-4, MAI-16, MAI-21, MAI-26, MAI-38 \\
\hline Urumari stream & $2^{\circ} 27^{\prime} 28.4^{\prime \prime} \mathrm{S}-54^{\circ} 41^{\prime} 53.9^{\prime \prime} \mathrm{W}$ & 2 & URU-3, URU-7 \\
\hline Almeirim & $1^{\circ} 31^{\prime} 3,7^{\prime \prime} \mathrm{S}-52^{\circ} 28^{\prime} 22.7^{\prime \prime} \mathrm{W}$ & 7 & ALM-2, ALM-5, ALM-6, ALM-9, ALM-10, ALM-11, ALM-12 \\
\hline
\end{tabular}




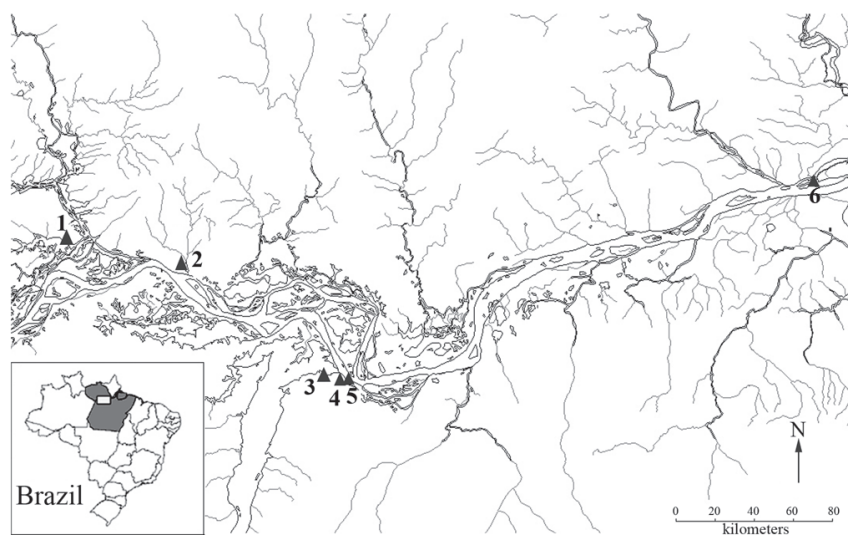

Fig. 1. Map of collection sites of Hoplias malabaricus in the lower Amazonas River. Localities: 1 - Sapucuá lake; 2 - Óbidos; 3 - Juá lake; 4 - Urumari stream; 5 - Maicá lake; 6 - Almeirim. A map of Brazil (box on left corner) with the Pará State shaded in gray indicates the studied area by a white rectangle.

with the primer M-13. Electrophoresis was conducted in an ABI 3500 automated DNA analyzer (Applied Biosystems).

\section{Data analysis}

For comparative analysis with specimens from distinct hydrographic basins additional sequences of Hoplias malabaricus (Accession numbers: HM405122.1; HM906019.1;
HM906020.1; HM405124.1; HM906018.1; JX111760-JX111763 ) were retrieved from the Genbank repository. Hoplias intermedius (Accession number: HM40513.1) had been added as outgroup to phylogenetic analysis. Sequences were aligned using ClustalW (Thompson et al., 1994) implemented in BioEdit 7.0.5.3 (Hall, 1999), followed by visual inspection for final adjustments. The quality of the database for phylogenetic analysis was checked by the saturation plot of transitions and transversions versus divergence, processed with Dambe v.4.2.13 (Xia \& Xie, 2001). Haplotype data were generated with DNAsp v.5.10.01 (Librado \& Rozas, 2009).

A preliminary phylogenetic reconstruction of the mitochondrial haplotypes was based on the Neighbor-Joining (NJ) method (Saitou \& Nei, 1987) using the Kimura 2 Parameters (K2P) substitution model implemented in MEGA v.5 (Tamura et al., 2011) following the routine analytical procedure established in previous DNA barcoding studies (www.boldsystems.org). The initial NJ analysis was complemented with Maximum Parsimony (MP) and Maximum Likelihood (ML) methods. Either complementary analysis was processed with MEGA v.5 and statistical support for the nodes was provided by a Bootstrap test with 1000 pseudoreplicates (Felsenstein, 1985). For the ML inference the best substitution model to explain the variation in the data was chosen by KAKUSAN v.4 (Tanabe, 2007), based on the Akaike Information Criteria (AIC).

Genetic distances between and within the identified haplogroups were calculated with MEGA v.5 using the Kimura2-parameter (K2P) model with rate variation among sites and

Table 2. Morphological measurements of Hoplias malabaricus from lower Amazon River. The measurement abbreviations are: standard length (LS); head length (LH); trunk length (TKL); head depth (HD); snout length (SNL); snout width (SNW); orbital diameter (OD); interorbital width (IOW); maxilla length (MXL); pectoral fin length (PFL); pelvic fin length (VFL); anal fin length (AFL); length of the base of the anal fin (LBA); length of the base of the dorsal fin (LBD); pre-pelvic distance (PVD); pre-dorsal distance (PDD); pre-anal distance (PAD); caudal peduncle depth (CPD); caudal peduncle length (CPL); distance from the lateral line to base of dorsal fin (DLLD). Measures taken in millimeters.

\begin{tabular}{|c|c|c|c|c|c|c|c|c|c|c|c|c|c|c|c|c|c|c|c|c|}
\hline & $L \mathrm{~S}$ & $L \mathrm{H}$ & KL & ID & NL & SNW & OD & IOW & MXL & PFL & FL & FL & LBA & LBD & PVD & PDD & PAD & $\mathrm{CPD}$ & & DLLD \\
\hline SAP-17 & 90.0 & 3.6 & 39.4 & & 19.7 & 20.2 & 10.9 & & 23.1 & & & & 15.0 & 33.2 & & 123.0 & & & & \\
\hline & & & & & & & & & & & & & & & & & & & & \\
\hline & & & & 16.4 & 14.6 & & & & 15 & 1 & & & 8. & & & 48 & & & & \\
\hline & 7.1 & 7.8 & 47.2 & 35.9 & 22.1 & 2 & 10 & 26.9 & 26.2 & 36.9 & & & 18.3 & 38.8 & 102 & 95.3 & & & & 19.3 \\
\hline & & 0.3 & 19.4 & 26.4 & 20.29 & 3.2 & 9. & 19 & 22.7 & 30.2 & 2.7 & & 14.0 & 33.1 & & 79.0 & & .0 & 3.6 & 7.2 \\
\hline & & 2.2 & 29.5 & 30.1 & 17.3 & 20. & & & 19.5 & 28.2 & 99 & & 17.6 & 36. & & 82.9 & & 3.1 & 5.9 & 6.6 \\
\hline & & 9.0 & 26.9 & 30.2 & & & & & 9 & 28.3 & & & 17.0 & & & 80.7 & & & .7 & 7.2 \\
\hline & & & & 32.6 & & & & & 0.5 & 31.7 & & & & & & 88.8 & & & & 0.2 \\
\hline & & & & & & & & & & & & & & & & & & & & \\
\hline & & & & & & & & & & & & & & & & & & & & 0.5 \\
\hline & & & & & & & & & & & & & & & & & & & & .3 \\
\hline & & & & & & & & & & & & & & & & 140.6 & & & & 1.5 \\
\hline & & & & & & & & & & & & & & & & & & & & 0.5 \\
\hline & & & & & & & & & & & & & & & & 75.6 & & & & 5.6 \\
\hline & & & & 40.1 & 7. & & 12 & & & & & & 22.7 & & & 121.2 & & & & 5.0 \\
\hline & & & 9.2 & & 4.9 & & & & & & & & 20.0 & 40.4 & & 95.9 & & & & 0.4 \\
\hline & & & & 29 & 1.6 & & & & & & & & 16 & & & 85.7 & & & & 19.9 \\
\hline & & & & 34 & & & & & & & & & 20 & & & 104.2 & & & & 2.6 \\
\hline & & & & & & & & & & & & & & & & 132.8 & & & & 8.4 \\
\hline & & & & 37.0 & & & & & & & & & & & & & & & & 3.8 \\
\hline & 5.0 & 1.9 & 78.1 & 37.4 & 69 & 8.7 & 12 & 1 & 153 & 25.8 & 33.3 & 34.6 & 13.5 & 45.7 & 121.1 & 116.9 & 194.5 & 23.1 & 23.7 & 28.6 \\
\hline
\end{tabular}


gamma shape distribution. The gamma shape parameter was estimated with PAUP v4b10 (Swofford, 1998).

\section{Results}

All the specimens analyzed presented $2 n=40$ chromosomes and a karyotypic formula with 20 metacentrics and 20 submetacentrics. The C-banded karyotype revealed heterochromatic blocks in the centromeres of all the chromosomes and telomeres in some of the pairs. A conspicuous and heteromorphic C-band was detected in the proximal region of chromosome 14 (Fig. 2).

The molecular dataset was based on partial 652-bp sequences of the mitochondrial COI gene of 44 specimens of Hoplias malabaricus and one of $H$. intermedius. No evidence of substitution saturation was found in the analysis of transition-transversions versus divergence. The fragment had 150 variable sites, 92 of which were informative for parsimony analysis. The sequences produced 35 haplotypes, which were used for phylogenetic analyses (Table 3). Haplotype 1 (Hap_1) represents the species $H$. intermedius, which was included as outgroup. The best evolutionary model fitted to the data was the HKY85 gamma model.

The phylogenetic analyses yielded gene trees with three major clades with strong statistical support. A closer examination of the tree topologies was concordant to highlight six haplogroups (Gp) and revealed slight differences in the positions of the groups 3 and 4. Furthermore, haplotype 29 was joined with Gp_ 4 by NJ analysis; however, such link has not been corroborated with ML and MP methods (Fig. 3, Table 3).

DNA barcodes successfully separated Hoplias malabaricus populations from Brazil (Gp 2-6) and Argentina (Gp1). In the other hand, Brazilian populations from distinct hydrographic regions, São Francisco and Amazonas River Basins, remained close together (Fig. 3). A common pattern

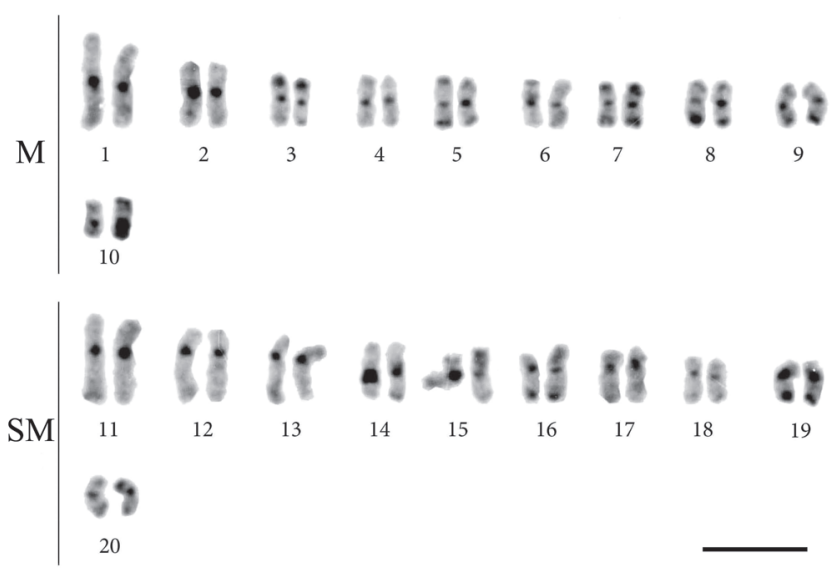

Fig. 2. C-banded karyotype of karyomorph $\mathrm{C}$ of Hoplias malabaricus, from lower Amazonas River. M - metacentric, SM - submetacentric. Bar $=10 \mu \mathrm{m}$. visualized in the Amazonian clades is the contribution of several sample sites to build each haplogroup node.

Due to Hap_29 not showed clear phylogenetic relationship with other clades we chosen remove it from the distance analysis among the haplogroups. The distances varied from $9 \%$ in Gp1 x Gp2 to $1.8 \%$ in Gp5 x Gp6 (Table 4). The largest distance within the group was found in Gp4 (2\%) and a comparison between Hoplias malabaricus and the outgroup $H$. intermedius revealed $16.4 \%$ of genetic divergence. We observed a mean distance of $8.6 \%$ when compared populations from Brazil (Gp2-6) to Argentina (Gp1).

\section{Discussion}

Cytogenetic markers have provided important criteria for the delimitation of H. malabaricus populations and the analysis of the evolutionary pathways of karyotypic diversification in this group (Bertollo et al., 2000; Cioffi et al., 2009; Jacobina et al., 2011; Vitorino et al., 2011). The chromosomal morphology and C-banding patterns of the H. malabaricus specimens analyzed in the present study were consistent with the $\mathrm{C}$ karyomorph lineage. This identification is supported by the diploid number $(2 \mathrm{n}=$ 40 ), the presence of 20 meta- and 20 submetacentrics in both males and females, and the C-banding pattern of the heteromorphic pair 14, which may be interpreted as homologous to pair 11 of the $\mathrm{C}$ karyomorph from Bento Gomes River described by Cioffi et al. (2009) and Cioffi \& Bertollo (2010). The heteromorphism of pair 14 appears to represent a signature of the nascent $\mathrm{XX} / \mathrm{XY}$ sex system indicated by karyomorph C (Cioffi \& Bertollo, 2010). However, the populations from the lower Amazon and Bento Gomes rivers diverged in their karyotypic formulae. In fact, a certain degree of intra-karyomorph variation would be expected, considering that the H. malabaricus complex is widely distributed in the river basins of South America and is known to contain high levels of karyotype polymorphism. Indeed, Blanco et al. (2010) recently reported extensive karyotypic variation in karyomorph A.

The DNA barcode analysis of Hoplias malabaricus revealed the presence of six haplogroups with a clear distinction between Brazilian and Argentinean populations. Additionally, similar levels of high genetic divergence could be observed between the Brazilian group Gp2 and the other populations. Recently, Rosso et al. (2012) argued for the strong geographic structure revealed by COI sequences of H. malabaricus from distant hydrographic basins in South America, and highlighted for the possibility of undiscovered species in the Pampa Plain region, Argentina. Our results corroborate the singularity of $H$. malabaricus from Argentina and show that deep genetic divergence also occurs in a smaller geographic scale as observed in populations from Amazon Basin.

Deep divergence in DNA barcode sequences thus appears to be a characteristic of Hoplias lineages. Previous studies have found high levels of divergence in Hoplias 
Table 3. Citochrome Oxidase I(COI) haplotypes of Hoplias malabaricus, except Hap_1 that is Hoplias intermedius. *Haplotype not included for distance estimation (see text for detail).

\begin{tabular}{|c|c|c|c|c|}
\hline Haplogroup & Haplotype & Frequency & Specimen & Geographic Unit \\
\hline - & Hap_1 & 1 & HM40513.1 & $\begin{array}{c}\text { Brazil, São Francisco } \\
\text { Basin }\end{array}$ \\
\hline \multirow{3}{*}{ GP 1} & Hap_2 & 1 & JX111763.1 & \multirow{3}{*}{ Argentina, Pampa plair } \\
\hline & Hap_3 & 1 & JX111762.1 & \\
\hline & Hap_4 & 2 & JX111761.1; JX111760.1 & \\
\hline \multirow{8}{*}{ Gp 2} & Hap_15 & 1 & MAI-4 & \multirow{8}{*}{ Brazil, Amazon Basin } \\
\hline & Hap_18 & 1 & MAI-38 & \\
\hline & Hap_21 & 1 & SAP-17 & \\
\hline & Hap_24 & 3 & OBI-11; OBI-14; OBI-15 & \\
\hline & Hap_25 & 1 & OBI- 12 & \\
\hline & Hap_26 & 1 & OBI-17 & \\
\hline & Hap_27 & 1 & OBI-18 & \\
\hline & Hap_28 & 1 & OBI-19 & \\
\hline \multirow{8}{*}{ Gp 3} & Hap_8 & 2 & ALM-2; ALM-6 & \multirow{8}{*}{ Brazil, Amazon Basin } \\
\hline & Hap_11 & 1 & ALM-11 & \\
\hline & Hap_13 & 1 & MAI-2 & \\
\hline & Hap_22 & 1 & OBI-1 & \\
\hline & Hap_23 & 1 & OBI-2 & \\
\hline & Hap_32 & 1 & JUA-14 & \\
\hline & Hap_33 & 1 & JUA-15 & \\
\hline & Hap_34 & 1 & URU-3 & \\
\hline \multirow{6}{*}{ Gp 4} & Hap_10 & 2 & ALM-9; ALM-10 & \multirow{6}{*}{ Brazil, Amazon Basin } \\
\hline & Hap_12 & 2 & ALM-12; MAI-16 & \\
\hline & Hap_14 & 1 & MAI-3 & \\
\hline & Hap_20 & 1 & SAP-3 & \\
\hline & Нар $29 *$ & 1 & JUA-3 & \\
\hline & Hap_35 & 1 & URU-7 & \\
\hline \multirow{3}{*}{ Gp 5} & Hap_5 & 2 & HM405122.1; HM906019.1 & \multirow{3}{*}{$\begin{array}{l}\text { Brazil, São Francisco } \\
\text { Basin. }\end{array}$} \\
\hline & Нар 6 & 2 & HM906020.1; HM405124.1 & \\
\hline & Hap_7 & 1 & HM906018.1 & \\
\hline \multirow{6}{*}{ Gp 6} & Hap_9 & 1 & ALM-5 & \multirow{6}{*}{ Brazil, Amazon Basin } \\
\hline & Hap_16 & 1 & MAI-21 & \\
\hline & Hap_17 & 1 & MAI-26 & \\
\hline & Hap_20 & 3 & SAP-1; SAP-4; SAP-5 & \\
\hline & Hap_30 & 1 & JUA-9 & \\
\hline & Hap_31 & 1 & JUA-13 & \\
\hline
\end{tabular}

malabaricus karyomorphs A and F from the São Francisco basin using the mitochondrial ATPase 6 marker. In this case, molecular divergence was accompanied by marked chromosomal variation, given that the A karyomorph is $2 \mathrm{n}$ $=42$ while $\mathrm{F}$ is $2 \mathrm{n}=40$ (Santos et al., 2009). If we assume that all the specimens collected in the present study $(35$ specimens) are representative of karyomorph $\mathrm{C}$, then this cytogenetic categorization should work with a range of genetic distance as high as the observed to discriminate distinct karyomorphs (A and F) and possibly distinct species. Such profound divergence in the DNA barcode within species indicates cryptic speciation or phylogeographic structuring. When it occurs between congener species, it may be explained by a long evolutionary history of diversification (De Carvalho et al., 2011).

Originally, Hebert et al. (2003) proposed that a divergence of $2-3 \%$ in the DNA barcode represents the threshold for the definition of species status in a lot of taxonomic groups. Several studies with fish groups have documented a larger range of genetic divergence (8-10\%) between congeneric species (Ward et al., 2005, 2009; Hubert et al., 2008; Lara et al., 2010; De Carvalho et al., 2011; Pereira et al., 2011). Similar levels of divergence were found herein among Hoplias malabaricus haplogroups, what can be interpreted as indicative of speciation event.

The effectiveness of DNA barcodes for the assessment of biodiversity and resolution of taxonomic problems, such as the identification of species, is currently under debate, although this approach has proven to be successful for delimiting species in a number of different animal groups (Hebert et al., 2004a, b; Clare et al., 2006; Ward et al., 2009). The results of the present study indicate that species-level genetic divergence within Hoplias malabaricus may not be restricted to populations with distinct karyomorphs, but even among individuals that present the same karyomorph, which indicates the possibility that different chromosomal races may also encompass species complexes. If the speciation process in $H$. malabaricus taken place without gross 

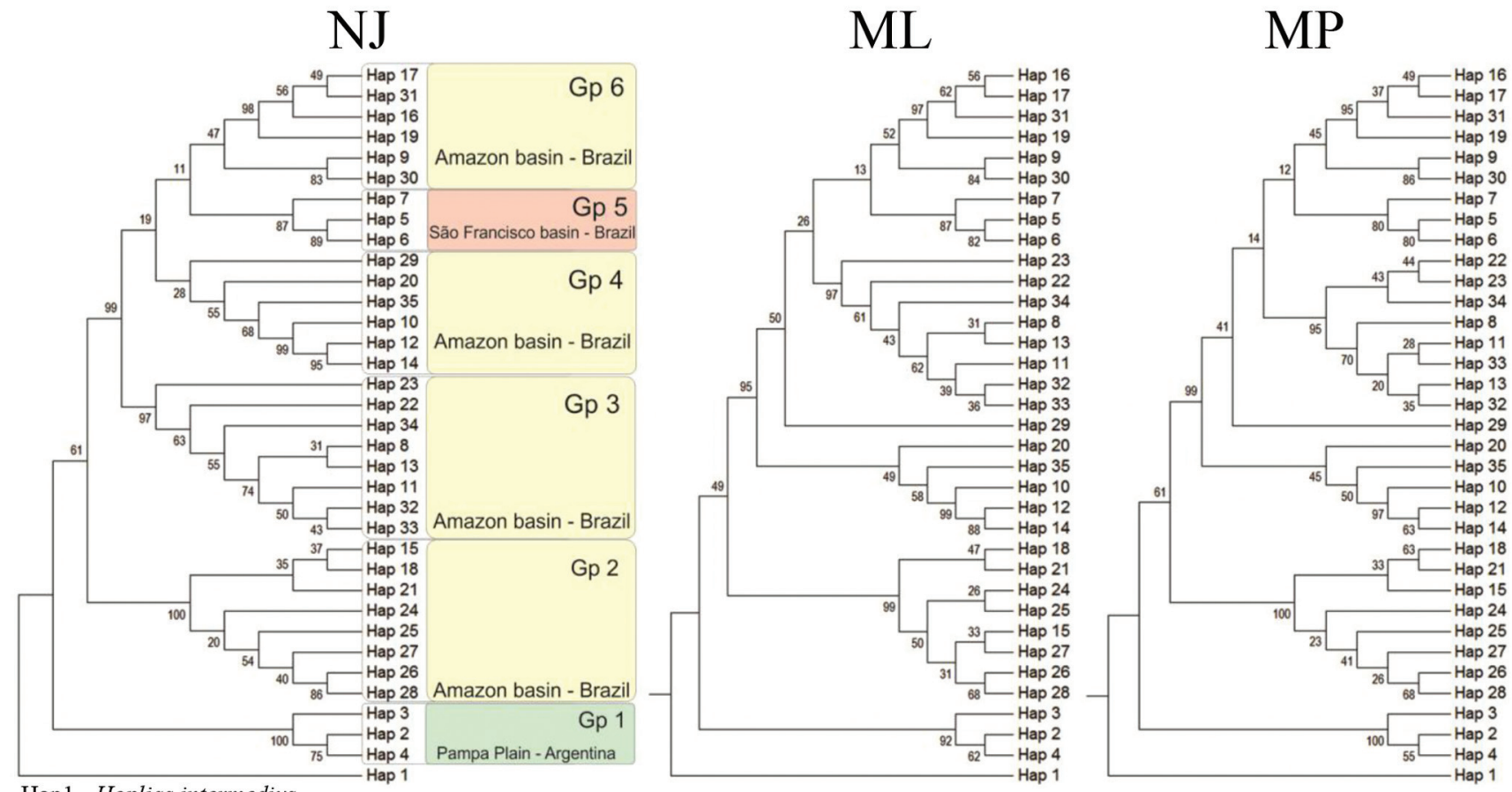

Hap1 - Hoplias intermedius

Fig. 3. Phylogenetic trees of Hoplias malabaricus haplotypes based on COI mitochondrial gene sequences. a) Neighbor-Joining; b) Maximum likelihood and c) Maximum Parsimony. Values in the nodes indicate the statistical support from bootstrap test.

modification in the karyotypes, as seems to be the case with the karyomorph $\mathrm{C}$, then the cytogenetic categorization that discriminate seven karyomorphs (A-G) should be carefully examined when interpreted as indicative of independent evolutionary units. It is clear that further studies based on the integrative approaches with genetic (molecular and

Table 4. Mean genetic distances of Hoplias malabaricus haplogroups estimated by Kimura-2-parameter algorithm adjusted with Gamma shape parameter $=1.00$. Standard Error (SE).

\begin{tabular}{|c|c|c|c|c|c|}
\hline \multicolumn{3}{|c|}{ Within groups } & \multicolumn{3}{|c|}{ Between groups } \\
\hline \multicolumn{3}{|c|}{ Mean } & \multicolumn{3}{|c|}{ Mean } \\
\hline Haplogroup & Distance & SE & Haplogroups & Distance & SE \\
\hline$G p 4$ & 0.020 & 0.004 & $G p 1 \times G p 2$ & 0.090 & 0.014 \\
\hline Gp 6 & 0.014 & 0.003 & $G p 6 \times G p 2$ & 0.086 & 0.013 \\
\hline$G p 2$ & 0.010 & 0.002 & $G p 1 \times G p 3$ & 0.086 & 0.013 \\
\hline$G p 3$ & 0.007 & 0.002 & $G p 1 \times G p 4$ & 0.085 & 0.013 \\
\hline$G p 1$ & 0.004 & 0.002 & $G p 1 \times G p 6$ & 0.085 & 0.013 \\
\hline \multirow[t]{10}{*}{$G p 5$} & 0.003 & 0.002 & $G p 3 \times G p 2$ & 0.083 & 0.013 \\
\hline & & & $G p 4 x G p 2$ & 0.082 & 0.012 \\
\hline & & & $G p 5 \times G p 2$ & 0.082 & 0.013 \\
\hline & & & $G p 1 \times G p 5$ & 0.076 & 0.013 \\
\hline & & & $G p 3 \times G p 4$ & 0.036 & 0.007 \\
\hline & & & $G p 6 \times G p 4$ & 0.033 & 0.006 \\
\hline & & & $G p 3 \times G p 6$ & 0.027 & 0.006 \\
\hline & & & $G p 5 \times G p 4$ & 0.025 & 0.005 \\
\hline & & & $G p 5 \times G p 3$ & 0.022 & 0.005 \\
\hline & & & $G p 5 \times G p 6$ & 0.018 & 0.004 \\
\hline
\end{tabular}

cytogenetic markers) and morphological data will be necessary for a more definitive understanding of the evolutionary relationships within the $H$. malabaricus complex.

\section{Acknowledgments}

The authors are grateful to the undergraduate students at the LGBio for chromosome preparations, the local fishermen who helped with the collection of specimens in the field, and J.A. Dergam for an initial revision of the manuscript. Financial support was given by INCT-ADAPTA (Conselho Nacional de Desenvolvimento Científico e Tecnológico - CNPq). DFM and FAS received fellowships from CAPES (Coordenação de Aperfeiçoamento de Pessoal de Nível Superior) and FAPESPA (Fundação de Amparo a Pesquisa do Estado do Pará).

\section{Literature Cited}

Allcock, A. L., I. Barratt, M. Eléaumei, K. Linse, M. D. Norman, P. J. Smith, D. Steinke, D. Stevens \& J. M. Strugnell. 2011. Cryptic speciation and the circumpolarity debate: A case study on endemic Southern Ocean octopuses using the COI barcode of life. Deep-Sea Research II, 58: 242-249.

Bertollo, L. A. C., K. S. Takahashi \& O. Moreira-Filho. 1978. Cytotaxonomic considerations on Hoplias lacerdae (Pisces Erythrinidae). Revista Brasileira de Genética, 2: 103-120.

Bertollo, L. A. C., G. G. Born, J. A. Dergam, A. S. Fenocchio \& O. M. Filho. 2000. A biodiversity approach in the neotropical Erythrinidae fish, Hoplias malabaricus. Karyotypic survey, 
geographic distribution of cytotypes and cytotaxonomic considerations. Chromosome Research, 8: 603-613.

Blanco, D. R., L. R. Lui, L. A. C. Bertollo, D. Diniz \& O. M. Filho. 2010. Characterization of invasive fish species in a river transposition region: evolutionary chromosome studies in the genus Hoplias (Characiformes, Erythrinidae). Reviews in Fish Biology and Fisheries, 20: 1-8.

Blaxter, M. L. 2004. The promise of DNA taxonomic. Proceedings of the Royal Society B., 359: 669-679.

Casiraghi, M., M. Labra, E. Ferri, A. Galimbert \& F. Mattia. 2010. DNA barcoding: a six-question tour to improve users' awareness about the method. Briefings in Bioinformatics, 2: 440-453.

Cioffi, M. B., C. Martins \& L. A. C. Bertollo. 2009. Comparative chromosome mapping of repetitive sequences. Implications for genomic evolution in the fish, Hoplias malabaricus. BMC Genetics, 10: 34 .

Cioffi, M. B. \& L. A. C. Bertollo. 2010. Initial steps in XY chromosome differentiation in Hoplias malabaricus and the origin of an $\mathrm{X}_{1} \mathrm{X}_{2} \mathrm{Y}$ sex chromosome system in this fish group. Heredity, 105: 554-561.

Clare, E. L., B. K. Lim, M. D. Engstrom, J. L. Eger \& P. D. N. Hebert. 2006. DNA barcoding of Neotropical bats: species identification and discovery within Guyana. Molecular Ecology Notes, 7: 184-190.

De Carvalho, D. C., D. A. A. Oliveira, P. S. Pompeu, C. G. Leal, C. Oliveira \& R. Hanner. 2011. Deep barcode divergence in Brazilian freshwater fishes: the case of the São Francisco River basin. Mitochondrial DNA, 22: 80-86.

Dergam, J. A., H. I. Suzuki, O. A. Shibatta, L. F. Duboc, H. F. Júlio Jr., L. Giuliano-Caetano \& W. C. Black IV. 1998. Molecular biogeography of the Neotropical fish Hoplias malabaricus (Erythrinidae: Characiformes) in the Iguaçu, Tibagi and Paraná Rivers. Genetics and Molecular Biology, 21: 493-496.

Dergam, J. A., S. R. Paiva, C. E. Schaeffer, A. L. Godinho \& Vieira, F. 2002. Phylogeography and RAPD-PCR variation in Hoplias malabaricus (Bloch, 1794) (Pisces, Teleostei) in southeastern Brazil. Genetics and Molecular Biology, 25: 379-387.

Felsenstein, J. 1985. Confidence limits on phylogenies: An approach using bootstrap. Evolution, 39:783-791.

Guindon, S. \& O. Gascuel. 2003. A simple, fast, and accurate algorithm to estimate large phylogenies by maximum likelihood. Systematic Biology, 52: 696-704.

Hall, T. 1999. Bioedit: a user-friendly biological sequence alignment editor and analysis program for windows 95/98/NT. Nucleic Acids Symposium Series, 41: 95-98.

Hebert, P. D. N., A. Cywinska, S. L. Ball \& J. R. Ward. 2003. Biological identifications through DNA barcodes. Proceedings of the Royal Society B, 270: 313-321.

Hebert, P. D. N., E. H. Penton, J. M. Burns, D. H. Janzen \& W. Hallwachs. 2004a. Ten species in one: DNA barcoding reveals cryptic species in the neotropical skipper butterfly Astraptes fulgerator. Plos Biology, 101: 14812-14817.

Hebert, P. D. N., M. Y. Stoeckle, T. S. Zemlak \& C. M. Francis. 2004b. Identifications of birds through DNA Barcodes. Plos Biology, 2: 1657-1663.

Hubert, N., R. Hanner, E. Holm, N. E. Mandrak, E. Taylor, M. Burridge, D. Watkinson, P. Dumont, A. Curry, P. Bentzen, J. Zhang, J. April \& L. Bernatchez. 2008. Identifying Canadian Freshwater Fishes through DNA Barcodes. Plos One, 3: 1-8.

Ivanova, N. V., T. S. Zemlak, R. H. Hanner \& P. D. N. Hebert. 2007. Universal primer cocktails for fish DNA barcoding. Molecular Ecology Notes, 7:544-548.
Jacobina, U. P., E. Paiva \& J. A. Dergam. 2011. Pleistocene karyotypic divergence in Hoplias malabaricus (Bloch, 1794) (Teleostei: Erythrinidae) populations in southeastern Brazil. Neotropical Ichthyology, 9: 325-333.

Kerr, K. C. R., M. Y. Stoeckle, C. J. Dove, L. A. Weigt, C. M. Francis \& P. D. N. Hebert. 2007. Comprehensive DNA barcode coverage of North American birds. Molecular Ecology Notes, 2:312

Kerr, K. C. R., D. A. Lijtmaer, A. S. Barreira, P. D. N. Hebert \& P. L. Tubaro. 2009. Probing evolutionary patterns in neotropical birds through DNA Barcodes. Plos One, 4: 4379.

Lara, A., J. L. P. León, R. Rodríguez, D. Casane, G. Côté, L. Bernatchez \& E. Machado. 2010. DNA barcoding of Cuban freshwater fishes: evidence for cryptic species and taxonomic conflicts. Molecular Ecology Resources, 10: 421-430.

Librado, P. \& J. Rozas. 2009. DnaSP v.5: a software for comprehensive analysis of DNA polymorphism data. Bioinformatics, 25: 1451-1452.

Lopes, P. A., A. J. Alberdi, J. A. Dergam \& A. S. Fenocchio. 1998. Cytotaxonomy of Hoplias malabaricus (Osteichthyes, Erythrinidae) in the Aguapey River (Province of Corrientes, Argentina). Copeia, 1998: 485-487.

Nelson, J. S. 2006. Fishes of the World. $4^{\text {th }}$ ed. New York, USA, John Wiley \& Sons.

Oyakawa, O. T. 2003. Family Erythrinidae. Pp. 238-240. In: Reis, R. E., S. O. Kullander \& C. J. Ferraris Jr., (Eds.). Check list of the freshwater fishes of South and Central America. Porto Alegre, EDIPUCRS.

Oyakawa, O. T. \& G. M. T Mattox. 2009. Revision of the Neotropical trahiras of the Hoplias lacerdae species-group (Ostariophysi: Characiformes: Erythrinidae) with descriptions of two new species. Neotropical Ichthyology, 7: 117-140.

Pazza, R. \& H. F. Júlio Jr. 2003. Occurrence of three sympatric cytotypes of Hoplias malabaricus (Pisces, Erythrinidae) in the Upper Paraná River. Cytologia, 68: 159-163.

Pereira, L. H. G., G. M. G. Maia, R. Hanner, F. Foresti \& C. Oliveira. 2011. DNA barcodes discriminate freshwater fishes from the Paraíba do Sul River basin, São Paulo, Brazil. Mitochondrial DNA, 22: 72-79.

Pereira, T. L., U. Santos, C. Schaefer, E. Carlos, G. O. Souza, S. R. Paiva, L. R. Malabarba, E. E. Schmidt \& J. A. Dergam. 2013. Dispersal and vicariance of Hoplias malabaricus (Bloch, 1794) (Teleostei, Erythrinidae) populations of the Brazilian continental margin. Journal of Biogeography, 40:905-914.

Piorsky, N. M. 2010. Diversidade genética e filogeografia das espécies Hoplias malabaricus (Bloch, 1794) e Prochilodus lacustris Steindachner, 1907 no nordeste do Brasil. Unpublished Ph.D. Dissertation, Universidade Federal de São Carlos, 152p.

Rosa, R., M. Caetano-Filho, O. A. Shibatta \& L. Giuliano-Caetano. 2009. Cytotaxonomy in distinct populations of Hoplias aff. malabaricus (Characiformes, Erythrinidae) from lower Paranapanema River basin. Journal of Fish Biology, 75: 26822694.

Rosso, J. J., E. Mabragaña, M. González Castro \& M. Díaz de Astarloa. 2012. DNA barcoding Neotropical fishes: recent advances from the Pampa Plain, Argentina. Molecular Ecology Resources, 12: 999-1011.

Saitou, N. \& M. Nei. 1987. The neighbor-joining method: a new method for reconstructing phylogenetic trees. Molecular Biology Evolution, 4: 406-425.

Sambrook, J., E. F. Fritsch \& T. Maniatis. 1989. Molecular cloning: a laboratory annual. $2^{\text {th }}$ ed. New York, NY, USA, Cold Spring Harbor Laboratory. 
Santos, U., C. M. Völcker, F. A. Belei, M. B. Cioffi, L. A. C. Bertollo, S. R. Paiva \& J. A. Dergam. 2009. Molecular and karyotypic phylogeography in the Neotropical Hoplias malabaricus (Erythrinidae) fish in eastern Brazil. Journal of Fish Biology, 75: 2326-2343.

Scavone, M. D. P., L. A. C. Bertollo \& M. M. Cavallini. 1994. Sympatric occurrence of two karyotypic forms of Hoplias malabaricus (Pisces, Erythrinidae). Cytobios, 80: 223-227.

Steinke, D., T. S. Zemlak, J. A. Boutillier \& P. D. N. Hebert. 2009. DNA barcoding of pacific Canada's fishes. Marine Biology, 156: 2641-2647.

Sumner, A. T. 1972. A simple technique for demonstrating centromeric heterochromatin. Experiments Cell Research, 75: 304-306.

Swofford, D. 1998. PAUP - Phylogenetic Analysis Using parsimony. Version 4.10 beta (Sinauer Associates, Suderland, MA).

Tamura, K., D. Peterson, N. Peterson, G. Stecher, M. Nei \& S. Kumar. 2011. MEGA5: Molecular Evolutionary Genetics Analysis Using Maximum Likelihood, Evolutionary Distance, and Maximum Parsimony Method. Molecular Biology and Evolution, 28: 2731-2739.

Tanabe, A. S. 2007. KAKUSAN: a computer program to automate the selection of a nucleotide substitution model and the configuration of a mixed model on multilocus data. Molecular Ecology, 7: 962-964.
Thompson, J. D., D. G. Higgins \& T. J. Gibson. 1994. CLUSTAL $\mathrm{W}$ : improving the sensitivity of progressive multiple sequence alignment through sequence weighting, position specific gap penalties and weight matrix choice. Nucleic Acids Research, 22: 4673-4680.

Vitorino, C. A., L. I. Souza, J. N. Rosa, G. T. Valente, C. Martins \& P. C. Venere. 2011. Molecular cytogenetics and its distribution to the understanding of the chromosomal diversification in Hoplias malabaricus (Characiformes). Journal of Fish Biology, 78: 1239-1248.

Ward, R. W., T. S. Zemlak, B. H. Innes, P. R. Last \& P. D. N. Hebert. 2005. DNA barcoding Australia's fish species. Philosophical Transactions of the Royal Society B, 360: 18471857.

Ward, R. D., R. Hanner \& P. D. N. Hebert. 2009. The campaign to DNA barcode all fishes, FISH-BOL. Journal of Fish Biology, 74: 329-356.

Xia, X. \& Z. Xie. 2001. DAMBE: Data analysis in molecular biology and evolution. Journal of Heredity, 92: 371-373.

Submitted October 8, 2012 Accepted March 1, 2013 by Claudio Oliveira

Published June 28, 2013 